\title{
PENGARUH EFIKASI DIRI DAN LINGKUNGAN SEKOLAH TERHADAP KECURANGAN AKADEMIK PADA MATA PELAJARAN IPS TERPADU
}

\author{
Ida Puspitasari \\ e-mail: idapuspita0868@gmail.com \\ Agus Priyono \\ e-mail: aguspriyono@unikama.ac.id \\ Udik Yudiono \\ e-mail: u_yudiono@unikama.ac.id
}

(Program Studi Pendidikan Ekonomi, Fakultas Ekonomika dan Bisnis, Universitas Kanjuruhan, Malang)

\begin{abstract}
This study aims to analyze effect of self efficacy and school environment on fraud academic on the subjects of IPS Terpadu students of class VII SMP Negeri 3 Kepanjen. This research uses quantitative approach, this type of research is ex post facto. Statistical data of the study using multiple linear regression. The population in this research is all student of class VII SMP Negeri 3 Kepanjen amounted to 320 students, research sampling technique using proportional random sampling number of 60 students. The results of the research are: (1) Negative and significant influence between self efficacy and school environment on fraud academic on IPS Terpadu subjects class VII SMP Negeri 3 Kepanjen, 2) The negative and significant effect of self efficacy on fraud academic on the subjects of IPS Terpadu VII grade students of SMP Negeri 3 Kepanjen, 3) Negative effects and significant of school environment against fraud academic on the subjects of Social Studies IPS Integrated grade VII SMP Negeri 3 Kepanjen.
\end{abstract}

Keywords : Self efficacy, School environment, Fraud academic.

Abstrak: Penelitian ini bertujuan untuk menganalisis pengaruh efikasi diri dan lingkungan sekolah terhadap kecurangan akademik pada mata pelajaran IPS Terpadu siswa kelas VII SMP Negeri 3 Kepanjen Penelitian ini menggunakan pendekatan kuantitatif, jenis penelitian ini adalah ex post facto. Data statistik penelitian menggunakan regresi linier berganda. Populasi dalam penelitian ini adalah seluruh siswa kelas VII SMP Negeri 3 Kepanjen berjumlah 320 siswa, teknik pengambilan sampel penelitian menggunakan proportional random sampling sejumlah 60 siswa. Hasil penelitian terdapat: (1) Pengaruh negatif dan signifikan antara efikasi diri dan lingkungan sekolah terhadap kecurangan akademik pada mata pelajaran IPS Terpadu siswa kelas VII SMP Negeri 3 Kepanjen, 2) Pengaruh negatif dan signifikan efikasi diri terhadap kecurangan akademik pada mata pelajaran IPS Terpadu siswa kelas VII SMP Negeri 3 Kepanjen, 3) Pengaruh negatif dan signifikan lingkungan sekolah terhadap kecurangan akademik pada mata pelajaran IPS Terpadu siswa kelas VII SMP Negeri 3 Kepanjen.

Kata kunci : Efikasi Diri, Lingkungan Sekolah, Kecurangan Akademik 


\section{PENDAHULUAN}

Pendidikan mempunyai peran yang sangat penting dalam kehidupan suatu bangsa, maju atau tidaknya suatu bangsa dipengaruhi oleh kualitas pendidikan dari bangsa itu sendiri. Pendidikan mengemban tugas untuk menghasilkan sumber daya manusia yang berkualitas bagi pembangunan bangsa dan negara. Oleh karena itu, pemerintah senantiasa berupaya untuk meningkatkan kualitas pendidikan agar kelak pendidikan di Indonesia mampu mencetak generasi yang mampu bersaing dengan negara lain.

Sistem pendidikan di Indonesia telah mencanangkan Pendidikan Karakter sebagai batu loncatan pembentukan karakter peserta didik, salah satunya adalah karakter jujur. Karakter jujur menjadi karakter yang secara spesifik perlu diberi penekanan (Suparlan, 2012), kejujuran yang berkaitan dengan peserta didik salah satunya adalah kejujuran dalam bidang akademik. Kejujuran akademik merupakan suatu hal yang seharusnya diterapkan oleh seluruh peserta didik, namun kini kejujuran akademik menjadi hal yang langka. Kejujuran akademik banyak digantikan oleh praktikpraktik kecurangan akademik. Perilaku kecurangan akademik tentu menjadi masalah bagi peserta didik itu sendiri, bagi sekolah dan bagi bangsa ini pada umumnya. Tingkat kecurangan akademik yang tinggi menjadi masalah bagi diri peserta didik itu sendiri, karena dengan melakukan hal yang tidak jujur pada saat mengerjakan ujian maupun tugas, peserta didik tidak bisa mengukur kemampuannya sendiri secara valid. Kecurangan akademik menjadi masalah bagi sekolah dimana prestasi yang dimiliki peserta didiknya ternyata tidak murni dari hasil kemampuan yang dimiliki oleh peserta didik tersebut, sehingga prestasi yang didapatkan tersebut tidak mencerminkan keadaan yang sebenarnya.

Faktor internal yang mempengaruhi perilaku kecurangan akademik adalah efikasi diri. Efikasi diri merupakan keyakinan pada kemampuan yang dimiliki seseorang untuk melakukan tindakan yang diperlukan dalam mencapai keberhasilannya. Efikasi diri pada peserta didik untuk mencapai keberhasilannya dalam bidang akademik masih rendah, ini terbukti pada kesiapan peserta didik dalam mengikuti ujian masih kurang sehingga sehingga masih saja ditemukan peserta didik yang melakukan kecurangan akademik. Peserta didik yang memiliki kepercayaan diri tinggi ia akan bertindak jujur dalam mengerjakan tugas maupun ujian. Sebaliknya, peserta didik yang memiliki kepercayaan diri rendah akan melakukan perilaku kecurangan akademik dalam mengerjakan tugas maupun ujian. Selain faktor internal yang mempengaruhi perilaku kecurangan akademik pada peserta didik juga terdapat faktor eksternal yang turut mempengaruhi perilaku kecurangan akademik.

Faktor eksternal yang mempengaruhi kecurangan akademik adalah lingkungan sekolah. Faktor lingkungan sekolah yang terkait dengan kecurangan akademik meliputi kelompok teman sebaya di sekolah, peraturan sekolah dan sikap guru terhadap perilaku kecurangan akademik. Kecurangan akademik dilakukan ketika peserta didik mengerjakan tugas dari guru mata pelajaran IPS Terpadu dan mengerjakan ujian mata pelajaran IPS Terpadu. Akan tetapi, kecurangan akademik dalam ujian mata pelajaran IPS Terpadu lebih banyak dilakukan daripada ketika mengerjakan tugas mata pelajaran IPS Terpadu yang diberikan oleh guru. Bentuk kecurangan akademik yang biasa dilakukan oleh peserta didik ketika ujian adalah bertanya kepada teman, bekerja sama dengan teman ketika ujian berlangsung, melihat jawaban teman dan menyalinnya ketika ujian, membiarkan teman melihat jawaban atau memberitahukan jawaban soal ujian ketika teman bertanya, membuka buku pegangan atau buku catatan ketika ujian, serta membawa dan membuka catatan selama ujian berlangsung. Peserta didik yang pernah melihat teman sebayanya melakukan perilaku kecurangan akademik seperti menyontek akan cenderung untuk meniru hal yang serupa. Demikian pula dengan ada atau tidaknya sanksi yang diterapkan di sekolah mengenai perilaku kecurangan akademik turut mempengaruhi perilaku kecurangan akademik peserta didik. 
Penelitian ini bertujuan untuk menganalisis: (1) Pengaruh efikasi diri dan lingkungan sekolah terhadap kecurangan akademik pada mata pelajaran IPS Terpadu siswa kelas VII SMP Negeri 3 Kepanjen. (2) Pengaruh efikasi diri terhadap kecurangan akademik pada mata pelajaran IPS Terpadu siswa kelas VII SMP Negeri 3 Kepanjen. (3) Pengaruh lingkungan sekolah terhadap kecurangan akademik pada mata pelajaran IPS Terpadu siswa kelas VII SMP Negeri 3 Kepanjen.

\section{TINJAUAN PUSTAKA}

\section{Kecurangan Akademik}

Menurut Lambert, Hogan, dan Barton dalam Latifah (2014: 13) mendefinisikan kecurangan akademik secara luas sebagai tindakan curang atau upaya oleh siswa untuk menggunakan cara-cara yang tidak sah atau tidak dapat diterima dalam setiap karya akademik. Menurut Kamus Besar Bahasa Indonesia (2010: 854) kata contek berasal dari kata sontek yang artinya mengutip sebagaimana aslinya atau bisa dikatakan sebagai menjiplak hasil karya orang lain.Sedangkan Menurut Dellington dalam Dody Hartanto (2012: 10) mengatakan bahwa menyontek merupakan upaya yang dilakukan seseorang untuk mendapatkan keberhasilan dengan cara-cara yang tidak jujur.

Kecurangan akademik secara luas adalah suatu sikap atau perilaku tidak jujur yang dilakukan oleh peserta didik dalam kegiatan akademik untuk memperoleh hasil yang memuaskan. Kecurangan akademik yang sering disebut dengan perilaku menyontek merupakan suatu hal yang tidak sah atau tidak dibenarkan yang dilakukan oleh seorang siswa ketika mngerjakan tugas maupun ujian untuk mendapatkan nilai yang tinggi.

Banyak faktor yang mempengaruhi seseorang untuk melakukan perilaku kecurangan, baik faktor personal maupun faktor situasional. Faktor personal digolongkan menjadi empat kategori yaitu: 1) Demografi (usia, jenis kelamin, perbedaan kebudayaan), 2) Kepribadian (dorongan mencari sensasi, self control, perkembangan moral dan sikap, locus of control), 3) Motivasi (tujuan dan alasan dalam pembelajaran), 4) Akademik meliputi kemampuan, subjek area, institusi dan organisasi. Sedangkan faktor situasional meliputi: 1) Ketegangan atau kecemasan, 2) Malas untuk belajar, 3) Berada dalam kondisi yang terjepit, 4) Pengakuan atau persetujuan terhadap tindakan menyontek (Endang Pudjiastuti, 2012: 107)

\section{Efikasi Diri}

Bandura (2009: 3) mengemukakan bahwa efikasi diri merupakan keyakinan pada kemampuan seseorang untuk mengatur dan melakukan serangkaian tindakan yang diperlukan dalam mencapai keinginannya. Menurut Kreitner dan Kinicki (2007) dalam Endang Pudjiastuti (2012: 107), efikasi diri akan mempengaruhi proses motivasi seseorang, yaitu setelah orang tersebut tahu dan yakin akan kemampuannya, mereka merasa mampu melaksanakan tugasnya, maka motivasinya juga akan lebih kuat dalam menyelesaikan tugas tersebut.

Adapun menurut Ormrod (2008) dalam Agus Purwanto (2015: 11) mengatakan bahwa efikasi diri (self-efficacy) adalah penilaian seseorang pada kemampuan yang ada pada dirinya sendiri untuk melakukan perilaku tertentu atau mencapai tujuan tertentu.

Berdasarkan beberapa pengertian tersebut dapat disimpulkan bahwa efikasi diri dalam aspek akademik dimaksudkan sebagai keyakinan manusia akan kemampuannya untuk melakukan serangkaian tindakan untuk mencapai keberhasilan akademiknya. Seorang individu yang memiliki efikasi diri yang tinggi berarti memiliki keyakinan yang tinggi untuk mencapai keberhasilan akademik dengan kemampuan yang ada pada dirinya. 
Endang Pudjiastuti (2012: 105) menyatakan bahwa terdapat beberapa faktor yang mempengaruhi efikasi diri yaitu:1) Faktor orientasi kendali diri, 2) Faktor situasional, 3) Status atau peran individu dalam lingkungan, 4) Faktor insentif atau reward. Menurut Bandura (2009: 79) efikasi diri yang dipercaya oleh seseorang bersumber dari empat hal yaitu enactive mastery experiences, vicarious experiences, verbal persuasion, dan physiological and affective states.

\section{Lingkungan Sekolah}

Menurut Oemar Hamalik (2009: 195) "lingkungan adalah segala sesuatu yang ada di alam sekitar yang memiliki makna atau pengaruh tertentu kepada individu". Oemar Hamalik (2010: 113) menyebutkan bahwa lingkungan sekolah merupakan faktor yang memiliki pengaruh besar terhadap perkembangan perilaku anak. Menurut Eko Putro Widyoko (2009) dalam Latifah (2014: 35) menyatakan bahwa menurut aliran behavioristik kegiatan belajar terjadi karena adanya kondisi atau stimulus dai lingkungan. Kegiatan belajar merupakan respon atau reaksi dari kondisi atau stimulus lingkungannya. Belajar atau tidaknya seseorang tergantung kepada faktor kondisional dari lingkungan. Lingkungan dapat berupa lingkungan keluarga, lingkungan masyarakat, maupun lingkungan sekolah. Lingkungan sekolah terdiri dari guru, media pembelajaran, buku teks, kurikulum, teman sekolah, peraturan sekolah, maupun sumber-sumber belajar lainnya.

Lingkungan sekolah merupakan lingkungan di sekolah yang mempengaruhi sikap peserta didik dalam bidang akademik, bisa diketahui bahwa lingkungan sangat mempengaruhi proses belajar peserta didik termasuk bagaimana peserta didik bertingkah laku. Kecurangan akademik yang dilakukan oleh peserta didik juga dipengaruhi oleh lingkungan sekitarnya, terutama lingkungan sekolah tempat di mana peserta didik tersebut belajar. Menurut Slameto (2008: 64) indikator dalam mengukur lingkungan sekolah sebagai berikut: 1) Metode mengajar, 2) Kurikulum, 3) Relasi guru dengan siswa, 4) Relasi siswa dengan siswa, 5) Disiplin sekolah, 6) Alat pelajaran, 7) Waktu sekolah.

\section{METODE}

Penelitian ini menggunakan pendekatan kuantitatif. Jenis penelitian ini adalah ex post facto. Metode yang digunakan dalam penelitian ini dengan regresi linier berganda. Penelitian ini dilaksanakan di SMP Negeri 3 Kepanjen, populasi dalam penelitian ini sejumlah 320 siswa kelas VII SMP Negeri 3 Kepanjen. Teknik pengambilan sampel menggunakan proportional random sampling, sampel dalam penelitian ini sebanyak 60 siswa kelas VII SMP Negeri 3 Kepanjen atau 20\% dari populasi. Teknik pengambilan data menggunakan angket, karena angket dirasa lebih efisien dan cocok untuk digunakan untuk pengambilan data dalam penelitian ini. Data variabel yang dikumpulkan menggunakan angket yaitu, efikasi diri, lingkungan sekolah dan kecurangan akademik.

\section{HASIL DAN PEMBAHASAN}

Berdasarkan permasalahan tersebut, analisis kontribusi efikasi diri dan lingkungan sekolah terhadap kecurangan akademik pada mata pelajaran IPS Terpadu. Berikut ini adalah hasil analisis data dan pengujian hipotesis yang telah dilakukan. 


\section{Hasil Uji F (Uji Secara Simultan)}

\begin{tabular}{|c|c|c|c|c|c|c|}
\hline \multicolumn{7}{|c|}{ ANOVA $^{a}$} \\
\hline \multicolumn{2}{|c|}{ Model } & Sum of Squares & Df & Mean Square & $\mathrm{F}$ & Sig. \\
\hline \multirow[t]{4}{*}{1} & Regression & 1577,460 & 2 & 788,730 & 313,790 &, $000^{\mathrm{b}}$ \\
\hline & Residual & & & & & \\
\hline & & 143,273 & 57 & 2,514 & & \\
\hline & Total & 1720,733 & 5 & & & \\
\hline & dictors: (C & tant), Efikasi Di & ingkun & $\operatorname{ran}$ Sekolah & & \\
\hline & ependent $\mathrm{V}$ & bel: Kecurangan & ademik & & & \\
\hline
\end{tabular}

Sumber: Hasil olahan SPSS versi 22.00 for

Windows

Hasil Uji t (Uji Signifikan Parsial)

\begin{tabular}{|l|l|c|c|c|}
\hline \multicolumn{4}{|c|}{ Coefficients $^{\mathrm{a}}$} \\
\multicolumn{2}{|l|}{ Model } & T & Sig. & Keterangan \\
\hline 1 & (Constant) & 35,422 &, 000 & - \\
& Efikasi Diri & $-13,908$ &, 000 & Negatif Signifikan \\
& Lingkungan & & & \\
& Sekolah & $-5,138$ &, 000 & Negatif Signifikan \\
\hline $\begin{array}{l}\text { Dependent variabel: Kecurangan } \\
\text { akademik }\end{array}$
\end{tabular}

Sumber: Hasil olahan SPSS versi 22.00 for Windows

Uji $\mathbf{R}^{2}$ Model Summary

\begin{tabular}{|c|c|c|c|c|}
\hline \multicolumn{5}{|c|}{ Model Summary ${ }^{b}$} \\
\hline Model & $\mathrm{R}$ & R Square & $\begin{array}{l}\text { Adjusted R } \\
\text { Square }\end{array}$ & $\begin{array}{c}\text { Std. Error of the } \\
\text { Estimate }\end{array}$ \\
\hline 1 & ,957a & 917 & ,914 & 1,58542 \\
\hline \multicolumn{5}{|c|}{$\begin{array}{l}\text { a. Predictors: (Constant), Efikasi Diri, Lingkungan } \\
\text { Sekolah }\end{array}$} \\
\hline b. Depe & abel: Ke & ingan Akader & mik & \\
\hline
\end{tabular}

Sumber: Hasil olahan SPSS versi 22.00 for Windows

Berdasarkan Tabel Uji R2 mengidentifikasi bahwa berpengaruh antara variabel efikasi diri (X1) dan linkungan sekolah (X2) memiliki nilai koefisien korelasi 0,957 mendekati 1 memiliki makna bahwa variabel bebas efikasi diri (X1) dan lingkungan sekolah (X2) secara bersama-sama memiliki hubungan yang kuat dengan variabel terikat kecurangan akademik (Y). Nilai koefisien determinasi ( $R$ Square) menunjukkan besar kontribusi seluruh variabel bebas yaitu efikasi diri (X1) dan lingkungan sekolah (X2) terhadap kecurangan akademik(Y), jadi R Square 0,917 memiliki makna efikasi diri (X1) dan lingkungan sekolah (X2) mampu memberikan kontribusi sebesar 91,7\% terhadap kecurangan akademik $(Y)$ dengan demikian sisanya sebesar 8,3\% ditentukan oleh variabel lain yang tidak diteliti misalnya: broken home, kompetensi guru dan pergaulan teman sebaya. 
Untuk mengetahui pengujian hipotesis pertama maka menggunakan uji $\mathrm{F}$ dan untuk menguji hipotesis ke dua dan ketiga menggunakan uji t.

Efikasi Diri dan Lingkungan Sekolah terhadap Kecurangan Aakdemik pada Mata Pelajaran IPS Terpadu Siswa Kelas VII SMP Negeri 3 Kepanjen.

Hasil statistik menunjukkan bahwa ada pengaruh yang negatif dan signifikan efikasi diri (X1) dan lingkungan sekolah (X2) terhadap kecurangan akademik pada mata pelajaran IPS Terpadu (Y). Hal ini dibuktikan dari hasil analisis diperoleh nilai F sebesar 313,790 dengan tingkat signifikan 0,000 karena tingkat signifikan lebih kecil dari 0,05 yang artinya ada pengaruh negatif dan signifikan efikasi diri (X1) dan lingkungan sekolah (X2) secara bersama-sama (simultan) terhadap kecurangan akademik pada mata pelajaran IPS Terpadu siswa kelas VII SMP Negeri 3 Kepanjen (Y). Ini berarti semakin tinggi efikasi diri dan semakin baik lingkungan sekolah maka kecurangan akademik akan menurun.

\section{Efikasi Diri terhadap Kecurangan Akademik pada mata pelajaran IPS Terpadu siswa kelas VII} SMP Negeri 3 Kepanjen.

Hasil analisis statistik menunjukkan bahwa ada pengaruh yang negatif dan signifikan antara efikasi diri terhadap kecurangan akademik pada mata pelajaran IPS Terpadu siswa kelas VII SMP Negeri 3 Kepanjen.

Hal ini dibuktikan dari hasil analisis uji t untuk variabel X1 (efikasi diri) sebesar -13,908 dengan tingkat signifikan sebesar 0,000. Karena tingkat signifikannya lebih kecil dari 0,05, yang artinya efikasi diri (X1) memiliki pengaruh yang negatif dan signifikan secara parsial terhadap kecurangan akademik pada mata pelajaran IPS Terpadu siswa kelas VII SMP Negeri 3 Kepanjen (Y). Ini berarti bahwa semakin tinggi efikasi diri maka kecurangan akademik akan semakin menurun.

Lingkungan sekolah terhadap kecurangan akademik pada mata pelajaran IPS Terpadu siswa kelas VII SMP Negeri 3 Kepanjen.

Hasil analisis statistik menunjukkan bahwa ada pengaruh yang negatif dan signifikan lingkungan sekolah terhadap kecurangan akademik pada mata pelajaran IPS Terpadu siswa kelas VII SMP Negeri 3 Kepanjen. Hal ini dibuktikan dari hasil analisis uji t untuk variabel X2 (lingkungan sekolah) sebesar -5,138 dengan tingkat signifikan sebesar 0,000. Karena tingkat signifikan lebih kecil dari 0,05 yang artinya lingkungan sekolah (X2) memiliki pengaruh yang negatif dan signifikan terhadap kecurangan akademik pada mata pelajaran IPS Terpadu siswa kelas VII SMP Negeri 3 Kepanjen (Y). Ini dapat diartikan bahwa lingkungan sekolah yang semakin baik maka kecurangan akademik semakin menurun.

\section{KESIMPULAN}

Berdasarkan hasil analisis yang dikemukakan pada bab V, maka dapat ditarik beberapa kesimpulan sebagai berikut: (1) Terdapat pengaruh negatif dan signifikan secara simultan antara efikasi diri dan lingkungan sekolah terhadap kecurangan akademik pada mata pelajaran IPS Terpadu siswa kelas VII SMP Negeri 3 Kepanjen. (2) Terdapat pengaruh negatif dan signifikan secara parsial efikasi diri terhadap kecurangan akademik pada mata pelajaran IPS Terpadu siswa kelas VII SMP Negeri 3 Kepanjen. (3) Terdapat pengaruh negatif dan signifikan secara parsial lingkungan sekolah terhadap kecurangan akademik pada mata pelajaran IPS Terpadu siswa kelas VII SMP Negeri 3 Kepanjen. 
Terpadu

\section{DAFTAR PUSTAKA}

Bandura, Albert. 2009. Self-Efficacy The Exercise of Control. New York: W.H. Freeman and Company. Hamalik, Oemar. 2009. Proses Belajar Mengajar. Bandung: Sinar Baru Algesindo. 2010. Psikologi Belajar dan Mengajar. Bandung: Sinar Baru Algesindo.

Hartanto, Dody. 2012. Bimbingan \& Konseling Menyontek Mengungkap Akar Masalah dan Solusinya. Jakarta: Indeks.

Hendra. 2012. Hubungan antara Efikasi Diri dan Orientasi Akademik dengan Perilaku Menyontek Siswa pada Mata Pelajaran Matematika. Tesis. Surakarta: Universitas Muhammadiyah Surakarta.

Latifah, Amalia N. 2014. Pengaruh Efikasi Diri, Disiplin Belajar dan Lingkungan Sekolah terhadap Kecurangan Akademik pada Tes Tertulis Akuntansi Siswa Kelas XI Kompetensi Keahlian Akuntansi SMK Se-Kabupaten Kulon Progo Tahun Ajaran 2013/2014. Skripsi. Yogyakarta: Universitas Negeri Yogyakarta.

Nora, W. L. Y., \& Zhang, K. C. 2010. Motives of Cheating among Secondary Students: The Role of Self-Efficacy and Peer Influence. Asia Pacific Education Review, (Online). 11(4): 573-584, (http://link.springer.com/article/10.1007/s12564-010-9104-2), diakses 6 November 2017.

Pujiastuti, Endang. 2012. Hubungan Self Efficacy dengan Perilaku Menyontek Mahasiswa Fakultas Psikologi. Mimbar, (Online). 28 (1): 103-112, (http://ejournal.unisba.ac.id/index.php/mimbar/article/view/344/42), diakses 18 November 2017.

Purwanto, Agus. 2015. Pengaruh Efikasi Diri terhadap Perilaku Menyontek Siswa Kelas V Sekolah Dasar Negeri Se-Gugus II Kecamatan Pakem Kabupaten Sleman Tahun Ajaran 2014/2015. Skripsi. Yogyakarta: Universitas Negeri Yogyakarta.

Suparlan. 2012. Pendidikan Karakter, (Online (http://suparlan.com/2/2012/07/23/pendidikan-karakter/), diakses 12 November 2017.. 